\title{
Hyperinols A and B, Chymotrypsin Inhibiting Triterpenes from Hypericum oblongifolium
}

\author{
Sadia Ferheen, ${ }^{b}$ Ejaz Ahmed, ${ }^{a}$ Abdul Malik, ${ }^{*}, a$ Nighat Afza,,${ }^{b}$ Muhammad Arif Lodhi, ${ }^{a}$ and \\ Muhammad Iqbal CHOUDHARY ${ }^{a}$ \\ ${ }^{a}$ International Centre for Chemical Sciences, H.E.J. Research Institute of Chemistry, University of Karachi; Karachi- \\ 75270, Pakistan: and ${ }^{b}$ Pharmaceutical Research Center, PCSIR Karachi Laboratories Complex; Karachi-75280, Pakistan. \\ Received December 19, 2005; accepted April 4, 2006
}

\begin{abstract}
Hyperinols A (1) and B (2) are new taraxastane type triterpenes which have been isolated from the chloroform soluble fraction of Hypericum oblongifolium and their structures elucidated on the basis of spectroscopic data. Both showed significant inhibitory activity against chymotrypsin enzyme.
\end{abstract}

Key words Hypericum oblongifolium; Hyperiaceae; hyperinol A; hyperinol B; taraxastane triterpene; chymotrypsin inhibition

Hypericum oblongifolium WALL is an erect evergreen shrub usually $6-12 \mathrm{~m}$ high, belonging to the family Hyperiaceae which comprises 8 genera and 210 species. ${ }^{1)}$ Antifungal, antibiotic, antiviral and anticancer compounds have so far been isolated from the genus. H. oblongifolium is common on Khasia Hill at an altitude of $5000-6000 \mathrm{~m}$ in China and in the Himalaya Hills. ${ }^{1)}$ It has been used in traditional Chinese herbal medicine for the treatment of hepatitis, bacterial diseases, nasal hemorrhage and as a remedy for dog bites and the sting of bees. ${ }^{1-3)}$ The ethnopharmacological and chemotaxonomic importance prompted us to investigate the bioactive constituents of this species. The methanolic extract of $H$. oblongifolium showed strong cytotoxicity in a brine shrimp lethality test ${ }^{4,5)}$ Further pharmacological screening revealed strong inhibitory activity against chymotrypsin enzyme which was most pronounced in the chloroform fraction. Studies on this fraction have now resulted in the isolation and structural elucidation of hyperinols A (1) and B (2), new taraxastane type triterpenes. Both of these showed significant chymotrypsin inhibitory activity.

\section{Results and Discussion}

Hyperinol A (1) was obtained as colorless crystals and was positive in the Lieberman Burchard test for a triterpenoid. The molecular formula was deduced as $\mathrm{C}_{30} \mathrm{H}_{46} \mathrm{O}_{3}$ through HR-EI-MS which showed the $\mathrm{M}^{+}$peak at $\mathrm{m} / \mathrm{z} 454.3333$ (Calcd for $\mathrm{C}_{30} \mathrm{H}_{46} \mathrm{O}_{3}, 454.3346$ ). The IR spectrum showed absorption bands for hydroxyl group $\left(3600 \mathrm{~cm}^{-1}\right), \gamma$-lactone $\left(1764 \mathrm{~cm}^{-1}\right)$ and terminal double bond (3000, 1646, $\left.906 \mathrm{~cm}^{-1}\right)$. The broad band and DEPT ${ }^{13} \mathrm{C}-\mathrm{NMR}$ spectra displayed thirty carbon signals comprised of eight quaternary, five methine, eleven methylene and six methyl carbons. The carbonyl of the $\gamma$-lactone moiety resonated at $\delta 179.9$ while the olefinic carbons were observed at $\delta 154.0$ and 109.1, respectively. Two oxygenated carbons resonated at $\delta 90.5$, and 79.2. The ${ }^{1} \mathrm{H}-\mathrm{NMR}$ spectrum demonstrated the presence of six methyl groups, of which five were singlets $(\delta 0.78,0.86$, $1.00,1.14,1.30)$ and one was a doublet $(\delta 1.05, J=6.8 \mathrm{~Hz})$. In addition a hydroxymethine proton was observed at $\delta 3.21$ (dd, $J=11.2,4.9 \mathrm{~Hz}$ ) along with olefinic protons at $\delta 4.87$ and 4.96 as singlets. ${ }^{6-8)}$ The doublet at $\delta 2.00$ corresponded to H-18 in $\beta$ configuration. ${ }^{5)}$ Its smaller magnitude of coupling $(J=4.6 \mathrm{~Hz})$ confirmed the presence of $\beta$ and equatorial proton at the neighboring $\mathrm{C}-19$ position, thereby establishing the $\alpha$ and axial configuration of the secondary methyl group attached to C-19. ${ }^{8}$ ) These spectral data (Tables 1, 2) suggested that 1 was a taraxastane type triterpene with one hydroxyl group, $\gamma$-lactone and the terminal double bond.

The hydroxymethine proton showed connectivity to two other protons in the ${ }^{1} \mathrm{H}-{ }^{1} \mathrm{H}$ COSY spectrum. The correlation of the signal due to oxymethine carbon at $\delta 79.2$ with those of H-23 and H-24 of geminal dimethyl moiety in HMBC experiments allowed us to place the hydroxyl group at C-3. The

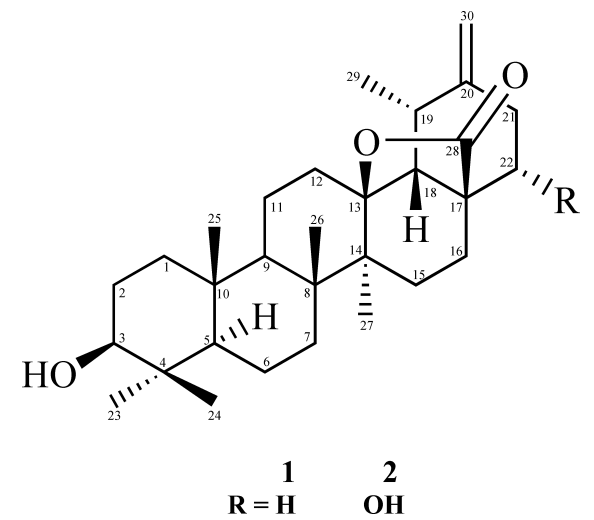

Fig. 1. Structures of Hyperinol A (1) and Hyperinol B (2)
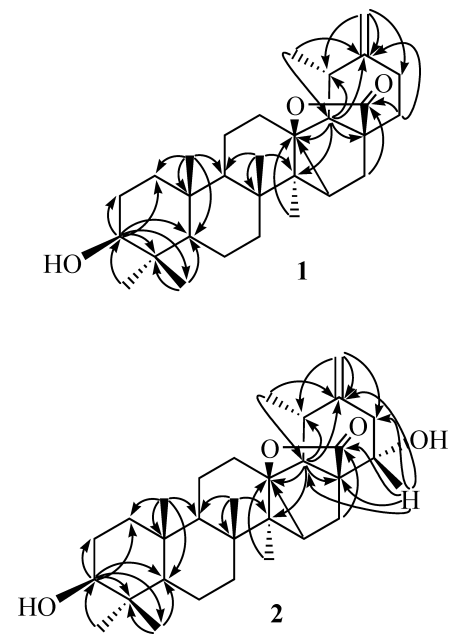

Fig. 2. Important HMBC Correlations of Hyperinol A (1) and Hyperinol B (2) 
Table 1. ${ }^{1} \mathrm{H}-\mathrm{NMR}$ Data of Compounds $\mathbf{1}$ and $\mathbf{2}$ at $400 \mathrm{MHz}$ in $\mathrm{CDCl}_{3}$

\begin{tabular}{cll}
\hline \hline Position & \multicolumn{1}{c}{$\mathbf{1}$} & \multicolumn{1}{c}{$\mathbf{2}$} \\
& \multicolumn{1}{c}{1} & \\
\hline 1 & $0.91(1 \mathrm{H}, \mathrm{m}), 1.73(1 \mathrm{H}, \mathrm{m})$ & $0.96(1 \mathrm{H}, \mathrm{m}), 1.74(1 \mathrm{H}, \mathrm{m})$ \\
2 & $1.55(1 \mathrm{H}, \mathrm{m}), 1.50(1 \mathrm{H}, \mathrm{m})$ & $1.54(1 \mathrm{H}, \mathrm{m}), 1.53(1 \mathrm{H}, \mathrm{m})$ \\
3 & $3.21(1 \mathrm{H}, \mathrm{dd}, 11.2,4.9)$ & $3.24(1 \mathrm{H}, \mathrm{dd}, 11.4,4.8)$ \\
5 & $0.74(1 \mathrm{H}, \mathrm{m})$ & $0.71(1 \mathrm{H}, \mathrm{m})$ \\
6 & $1.55(2 \mathrm{H}, \mathrm{m})$ & $1.38(2 \mathrm{H}, \mathrm{m})$ \\
7 & $1.38(2 \mathrm{H}, \mathrm{m})$ & $1.35(2 \mathrm{H}, \mathrm{m})$ \\
9 & $1.36(1 \mathrm{H}, \mathrm{dd}, 11.6,4.8)$ & $1.30(1 \mathrm{H}, \mathrm{dd}, 11.2,4.8)$ \\
11 & $1.25(1 \mathrm{H}, \mathrm{m}), 1.58(1 \mathrm{H}, \mathrm{m})$ & $1.28(1 \mathrm{H}, \mathrm{m}), 1.54(1 \mathrm{H}, \mathrm{m})$ \\
12 & $2.02(2 \mathrm{H}, \mathrm{m})$ & $2.00(2 \mathrm{H}, \mathrm{m})$ \\
15 & $1.89(1 \mathrm{H}, \mathrm{m}), 1.18(1 \mathrm{H}, \mathrm{m})$ & $1.85(1 \mathrm{H}, \mathrm{m}), 1.14(1 \mathrm{H}, \mathrm{m})$ \\
16 & $2.11(1 \mathrm{H}, \mathrm{m}), 1.24(1 \mathrm{H}, \mathrm{m})$ & $2.13(1 \mathrm{H}, \mathrm{m}), 1.20(1 \mathrm{H}, \mathrm{m})$ \\
18 & $2.00(1 \mathrm{H}, \mathrm{d}, J=4.6)$ & $1.98(1 \mathrm{H}, \mathrm{d}, J=4.6)$ \\
19 & $2.04(1 \mathrm{H}, \mathrm{dq}, J=4.6,6.8)$ & $2.04(1 \mathrm{H}, \mathrm{dq}, J=4.6,6.4)$ \\
21 & $2.21(1 \mathrm{H}, \mathrm{m}), 2.44,(1 \mathrm{H}, \mathrm{m})$ & $2.22(2 \mathrm{H}, \mathrm{m})$ \\
22 & $1.60(1 \mathrm{H}, \mathrm{m}), 1.55(1 \mathrm{H}, \mathrm{m})$ & $3.90(1 \mathrm{H}, \mathrm{dd}, J=4.8,2.5)$ \\
23 & $1.00(3 \mathrm{H}, \mathrm{s})$ & $0.95(3 \mathrm{H}, \mathrm{s})$ \\
24 & $0.78(3 \mathrm{H}, \mathrm{s})$ & $0.77(3 \mathrm{H}, \mathrm{s})$ \\
25 & $0.86(3 \mathrm{H}, \mathrm{s})$ & $0.84(3 \mathrm{H}, \mathrm{s})$ \\
26 & $1.14(3 \mathrm{H}, \mathrm{s})$ & $1.12(3 \mathrm{H}, \mathrm{s})$ \\
27 & $1.30(3 \mathrm{H}, \mathrm{s})$ & $1.31(3 \mathrm{H}, \mathrm{s})$ \\
29 & $1.05(3 \mathrm{H}, \mathrm{d}, J=6.8)$ & $1.02(3 \mathrm{H}, \mathrm{d}, J=6.4)$ \\
30 & $4.87(1 \mathrm{H}, \mathrm{s}), 4.96(1 \mathrm{H}, \mathrm{s})$ & $4.65(1 \mathrm{H}, \mathrm{s}), 4.85(1 \mathrm{H}, \mathrm{s})$. \\
& & \\
& &
\end{tabular}

The coupling constants are given in Hz. The assignments have been made with the help of HMQC.

Table 2. ${ }^{13} \mathrm{C}$-NMR Data of Compounds $\mathbf{1}$ and $\mathbf{2}$ at $100 \mathrm{MHz}$ in $\mathrm{CDCl}_{3}$

\begin{tabular}{|c|c|c|}
\hline Position & 1 & 2 \\
\hline 1 & 39.1 & 38.8 \\
\hline 2 & 27.6 & 27.5 \\
\hline 3 & 79.2 & 78.8 \\
\hline 4 & 39.1 & 38.8 \\
\hline 5 & 55.3 & 55.3 \\
\hline 6 & 18.2 & 18.2 \\
\hline 7 & 34.0 & 34.0 \\
\hline 8 & 40.8 & 40.8 \\
\hline 9 & 46.8 & 50.7 \\
\hline 10 & 36.2 & 37.4 \\
\hline 11 & 21.3 & 21.0 \\
\hline 12 & 27.6 & 27.8 \\
\hline 13 & 90.5 & 90.2 \\
\hline 14 & 42.3 & 42.0 \\
\hline 15 & 28.0 & 28.0 \\
\hline 16 & 21.3 & 21.0 \\
\hline 17 & 44.8 & 49.2 \\
\hline 18 & 51.6 & 54.1 \\
\hline 19 & 37.8 & 38.1 \\
\hline 20 & 154.0 & 154.8 \\
\hline 21 & 33.0 & 36.9 \\
\hline 22 & 28.0 & 90.5 \\
\hline 23 & 28.0 & 28.1 \\
\hline 24 & 15.6 & 15.4 \\
\hline 25 & 15.9 & 15.4 \\
\hline 26 & 18.9 & 18.0 \\
\hline 27 & 18.1 & 18.8 \\
\hline 28 & 179.9 & 178.8 \\
\hline 29 & 23.8 & 26.1 \\
\hline 30 & 109.1 & 109.8 \\
\hline
\end{tabular}

larger coupling constant indicated that the orientation of the hydroxyl group at C-3 was $\beta$ and equatorial. The carbonyl carbon signal at $\delta 179.9$ correlated with those of H-16 and $\mathrm{H}-22$, while the signal due to the carbon bearing lactone oxygen at $\delta 90.5$ correlated with those of H-15, H-18 and H-27. These results suggested that the carbonyl group and tertiary oxygen bond of a lactone moiety were connected to C-17 and $\mathrm{C}-13$, respectively. The olefinic carbon at $\delta 109.1$ correlated with H-19 and H-21. Similarly, the more downfield olefinic carbon at $\delta 154.0$ showed connectivity to $\mathrm{H}-18$ and $\mathrm{H}-22$, thereby establishing the presence of a terminal double bond at $\mathrm{C}-20$. The structure of hyperinol A (1) could thus be elucidated as $3 \beta$-hydroxy-20(30)-taraxastene-28,13 $\beta$-olide.

Hyperinol B (2) was obtained as colorless crystals and the Lieberman Burchard test showed it to be a triterpene. The molecular formula was determined as $\mathrm{C}_{30} \mathrm{H}_{46} \mathrm{O}_{4}$ by HR-EIMS showing an $\mathrm{M}^{+}$peak at $\mathrm{m} / z$ 470.3362 (Calcd for $\left.\mathrm{C}_{30} \mathrm{H}_{46} \mathrm{O}_{4}, 470.3396\right)$. The IR spectrum was very similar to that of 1 while the broad band and DEPT ${ }^{13} \mathrm{C}-\mathrm{NMR}$ showed thirty carbon signals comprising seven quaternary, seven methine, ten methylene and six methyl carbons.

The ${ }^{1} \mathrm{H}-\mathrm{NMR}$ spectrum was also similar to that of $\mathbf{1}$ expect for the presence of an additional equatorial hydroxymethine proton at $\delta 3.90(1 \mathrm{H}, \mathrm{dd}, J=4.8,2.5 \mathrm{~Hz})$. Both ${ }^{1} \mathrm{H}-$ and ${ }^{13} \mathrm{C}$ NMR spectra showed minor differences from those of 1 in the chemical shifts of the ring E, revealing the presence of the additional hydroxyl group in that ring. ${ }^{6,9)}$ In the HMBC spectrum the hydroxymethine proton at $\delta 3.90$ showed ${ }^{2} J$ correlations with C-21 ( $\delta 36.9), \mathrm{C}-17\left(\delta\right.$ 49.2) and ${ }^{3} J$ correlations with $\mathrm{C}-20(\delta$ 154.8), C-18 $(\delta$ 54.1) and C-16 $(\delta$ $21.0)$. This confirmed the presence of a hydroxyl group at $\mathrm{C}$ 22. The magnitude of coupling constant allowed us to assign $\alpha$ and axial orientation to the hydroxyl group which could also be confirmed through NOE experiments in which $\mathrm{H}-22$ showed interactions with both $\mathrm{H}-18$ and $\mathrm{H}-21 \beta$, respectively. Thus the structure of hyperinol B (2) was assigned as $3 \beta, 22 \alpha$-dihydroxy-20(30)-taraxastane-28,13 $\beta$-olide.

The importance of enzyme inhibitors as drugs is enormous since these molecules have been used for treating a number of physiological conditions. ${ }^{10)}$ Serine protease inhibitors have been proposed to be part of the plant's natural defense system against insect predation, and function by inhibiting insect proteinases. ${ }^{11-13)}$ Hence these inhibitors have gained attention as possible sources of engineered resistance against pests and pathogens for transgenic plants expressing heterologous inhibitors. ${ }^{14)}$ Chronic infection by hepatitis $\mathrm{C}$ virus can lead to progressive liver injury, cirrhosis, and liver cancer. A chymotrypsin like serine protease, known as NS3 protease, is thought to be essential for viral replication and has become a target for anti-HCV drugs. ${ }^{15)}$ The search for new and effective inhibitors of serine proteases is an urgent need in drug development, and new chymotrypsin inhibitors appear to be a promising approach. Both $\mathbf{1}$ and $\mathbf{2}$ showed moderate inhibitory activity against chymotrypsin (Table 2), although, compound $\mathbf{2}$ showed higher inhibitory potential than 1, probably due to the presence of an additional $\mathrm{OH}$ moiety at $\mathrm{C}-22$.

\section{Experimental}

General Experimental Procedure UV and IR spectra were recorded on Hitachi-UV-3200 and Jasco-320-A spectrometers, respectively. ${ }^{1} \mathrm{H}-$ and ${ }^{13} \mathrm{C}-\mathrm{NMR}$ spectra were recorded on a Bruker AM-400 spectrometer with tetramethylsilane (TMS) as an internal standard. The 2D-NMR spectra were recorded on a Bruker AMX 500 NMR spectrometer. Optical rotations were measured on a Jasco DIP-360 digital polarimeter using a $10 \mathrm{~cm}$ tube. Mass spectra (EI and HR-EI-MS) were measured in an electron impact mode on Finnigan MAT 12 and MAT 312 spectrometers and ions are given in $\mathrm{m} / \mathrm{z}$ (\%). TLC was performed on precoated silica gel $\mathrm{F}_{254}$ plates; the detection was done at $254 \mathrm{~nm}$ and by spraying with ceric sulphate reagent. Silica gel (E. Merck, 230 - 400 mesh) was used for column chromatography. Melting 
Table 3. In Vitro Quantitative Inhibition of Chymotrypsin

\begin{tabular}{lc}
\hline \multicolumn{1}{c}{ Substrate } & $\mathrm{IC}_{50} \pm$ S.E.M. ${ }^{a)}(\mu \mathrm{M})$ \\
\hline Methanolic extract & $10.33 \pm 0.041$ \\
$n$-Hexane fraction & nil \\
$\mathrm{CHCl}_{3}$ fraction & $35.54 \pm 0.041$ \\
EtOAc fraction & $69.29 \pm 0.028$ \\
$n$-BuOH fraction & $77.56 \pm 0.010$ \\
Hyperinol A (1) & $22.45 \pm 0.023$ \\
Hyperinol B (2) & $15.62 \pm 0.055$ \\
Chymostatin (positive control) & $8.01 \pm 0.11$ \\
\hline
\end{tabular}

a) Key: All the $\mathrm{IC}_{50}$ values are in micro molar quantity.

points were determined on a Gallenkemp apparatus and are uncorrected. All chemicals and chymotrypsin (bovine pancreas) for enzyme inhibition assays were purchased from Sigma Chemical Company (St. Louis, MO, U.S.A.).

Plant Material The whole plant of Hypericum oblongifolium WALL was collected from Kashmir, Pakistan in April 2004 and identified by Dr. Rubina Ashraf, Plant Taxonomist, National Agriculture Research Centre Islamabad, Pakistan, where a voucher specimen has been deposited.

Extraction and Purification The whole plant $(10 \mathrm{~kg})$ was extracted with methanol $(3 \times 251)$ at room temperature. The extract was evaporated to yield the residue $(550 \mathrm{~g})$, which was divided into $n$-hexane $(60 \mathrm{~g})$, chloroform $(75 \mathrm{~g})$, ethyl acetate $(40.5), n$-butanol $(50 \mathrm{~g})$ and water $(38 \mathrm{~g})$ soluble fractions. The chloroform-soluble fraction which showed major chymotrypsin inhibitory activity was subjected to column chromatography over silica gel eluting with $n$-hexane- $\mathrm{CHCl}_{3}, \mathrm{CHCl}_{3}, \mathrm{CHCl}_{3}-\mathrm{MeOH}$, in increasing order of polarity. The fractions which were obtained from $n$-hexane- $\mathrm{CHCl}_{3}$ (1.8:8.2), were combined and rechromatographed over silica gel eluting with $n$-hexane- $\mathrm{CHCl}_{3}$ in increasing order of polarity. The fractions obtained from $n$-hexane- $\mathrm{CHCl}_{3}(2: 8)$ were subjected to preparative TLC (nhexane- $\left.\mathrm{CHCl}_{3}: 1.5: 8.5\right)$ to afford the pure compounds $1(18 \mathrm{mg})$ and 2 (23 mg), respectively.

Hyperinol A (1): mp $260-262^{\circ} \mathrm{C} .[\alpha]_{\mathrm{D}}^{20}+75.1^{\circ}\left(c=0.3, \mathrm{CHCl}_{3}\right)$. IR $v_{\max } \mathrm{cm}^{-1}: 3600,1764,1646,1384,1373,1043,906 .{ }^{1} \mathrm{H}-\mathrm{NMR}$ see Table 1. ${ }^{13} \mathrm{C}-\mathrm{NMR}$ see Table 2. EI-MS $(70 \mathrm{eV}) \mathrm{m} / \mathrm{z}$ (rel. int. \%) $454\left(\mathrm{M}^{+}, 68\right), 436$ (60), 421 (41), 410 (58), 406 (53), 205 (100), 189 (96), 67 (45), 55 (52), 43 (61). HR-EI-MS $m / z \mathrm{M}^{+} 454.3333$ (Calcd for $\mathrm{C}_{30} \mathrm{H}_{46} \mathrm{O}_{3} 454.3346$ ).

Hyperinol B (2): mp $246-248^{\circ} \mathrm{C}$. $[\alpha]_{\mathrm{D}}^{25}+49.5^{\circ}\left(c=0.5, \mathrm{CHCl}_{3}\right)$. IR $v_{\max } \mathrm{cm}^{-1}: 3704,3620,1750,1715,1642,1370 .{ }^{1} \mathrm{H}-\mathrm{NMR}$ see Table $1 .{ }^{13} \mathrm{C}$ NMR see Table 2. EI-MS (70 eV) $m / z$ (rel. int. \%): $470\left(\mathrm{M}^{+}, 70\right), 452(60)$, 437 (45), 422 (65), 406 (85), 189 (100), 55 (46). HR-EI-MS m/z M 470.3362 (Calcd for $\mathrm{C}_{30} \mathrm{H}_{46} \mathrm{O}_{4} 470.3396$ ).

Chymotrypsin inhibitory activities of compounds $\mathbf{1}$ and $\mathbf{2}$ were deter- mined by the method of Cannel et al. ${ }^{16)}$ (Table 3). Chymotrypsin (9 units/ml of $50 \mu \mathrm{M}$ Tris- $\mathrm{HCl}$ buffer, $\mathrm{pH}$ 7.6) was preincubated with compounds 1 and 2 for $20 \mathrm{~min}$ at $25^{\circ} \mathrm{C}$. One hundred microliters of substrate solution $(N$-succinyl-phenylalanine-p-nitroanilide, $1 \mathrm{mg} / \mathrm{ml}$ of $50 \mu \mathrm{M}$ Tris- $\mathrm{HCl}$ buffer, $\mathrm{pH}$ 7.6) was added to start the enzyme reaction. The absorbance of released $p$ nitroaniline was continuously monitored at $410 \mathrm{~nm}$ until a significant color change was observed. The final DMSO concentration in the reaction mixture was $7 \%$.

Estimation of $\mathbf{I C}_{\mathbf{5 0}}$ Values The concentrations of test compounds $\mathbf{1}$ and 2 that inhibited the hydrolysis of substrates (chymotrypsin) by $50 \%\left(\mathrm{IC}_{50}\right)$ were determined by monitoring the effect of increasing concentrations of these compounds in the assays on the inhibition values. The $\mathrm{IC}_{50}$ values were then calculated using the EZ-Fit Enzyme Kinetics program (Perrella Scientific Inc., Amherst, Mass, U.S.A.).

\section{References}

1) Chopra R. N., Chopra I. C., Verma B. S., Supplement to Glossary of Indian Medicinal Plants, 1998, 347.

2) Yazaki K., Okada. T., "Biotechnology of Agricultural Forest. Medicinal and Aromatic Plants," VI, Vol. 26, ed. by Bajaja Y. P. S., SpringerVerlag, Berlin, 1994, pp. 167-169.

3) Chang Su New Medical College, "Dictionary of Chinese Crude Drugs," Shanghai Scientific Technological Publishers, Shanghai, 1994.

4) McLaughlin J. L., Chang C. J., Smith D. L., "Studies in Natural Products Chemistry," Vol. 9, ed. by Atta-Ur-Rahman, Elsevier, Amsterdam, 1997, pp. 383-490.

5) Meyer B. N., Ferrigni N. R., Putnam J. E., Jacobsen L. B., Nichols D. E., McLaughlin J. L., Planta Med., 45, 31-34 (1982).

6) Dai J., Zhao C., Zhang Q., Liu Z. L., Zheng R., Yang L., Phytochemistry, 58, 1107-1111 (2001).

7) Kuo Y. H., Chaiang Y. M., Chem. Pharm. Bull., 47, 498-500 (1999).

8) Petrovic S. D., Gorunovic M. S., Wray V., Merfort I., Phytochemistry, 50, 293-296 (1999).

9) Errington S. G., Jefferies P. R., Phytochemistry, 27, 543-545 (1988).

10) Amtul Z., Rahman A., Siddiqui R. A., Choudhary M. I., Curr. Med. Chem., 9, 1323-1327 (2002).

11) Boulter D., Gatehouse A. M. R., Hilder V., Biotechnol. Adv., 7, 487497 (1989).

12) Ryan C. A., Annu. Rev. Phytopathol., 28, 425-429 (1990)

13) Masoud S. A., Jhonson L. B., White F. F., Reeck G. R., Plant Mol. Biol., 21, 655-663 (1993).

14) Hilder V. A., Gatehouse A. M. R., Sheerman S. E., Barker R. F., Boulter D., Nature (London), 330, 160-162 (1987).

15) Patrick A. K., Potts K. E., Clin. Microbiol. Rev., 11, 614-617 (1998).

16) Cannell R. J. P., Kellam S. J., Owsianka A. M., Walker J. M., Planta Med., 54, 10-14 (1988). 